\title{
Treatment of abdominal tumors using radiotherapy
}

\author{
TRATAMENTO DE TUMORES ABDOMINAIS COM RADIOTERAPIA \\ Authorship: Brazilian Society for Radiation Oncology \\ Participants: Weltman E, Marta GN, Baraldi HS, Pimentel L, Castilho M, Maia MAC, Lundgren MSFS, Chen MJ, \\ Novaes PERS, Gadia R, Ferrigno R, Motta R, Hanna SA, Almeida W \\ Final draft: February 12, 2014
}

http://dx.doi.org/10.1590/1806-9282.61.02.108

The Guidelines Project, an initiative of the Brazilian Medical Association, aims to combine information from the medical field in order to standardize procedures to assist the reasoning and decision-making of doctors.

The information provided through this project must be assessed and criticized by the physician responsible for the conduct that will be adopted, depending on the conditions and the clinical status of each patient.

\section{Description OF THE EVIDENCE COLLECTION METHOD}

Through the development of three relevant clinical questions related with the proposed subject, we tried to present the main evidence for the safety, toxicity and effectiveness of the radiotherapy techniques in question. The study population consisted of male and female patients of all ages with abdominal tumors (stomach, pancreas, biliary tract and sarcomas) regardless of histological type, staging, treatment context (neoadjuvant, radical or adjuvant) of the disease, or the presence of comorbidities. For this, a systematic review of the literature was performed in primary scientific research databases (Medline - Pubmed; Embase - Elsevier; Lilacs - Bireme; Cochrane Library - Central Register of Controlled Trials). All articles available until November 30, 2012, were included. The keywords used in the search were: ("Retroperitoneal Neoplasms" OR "Sarcoma" OR "Abdomen" OR "intra-abdominal sarcoma" OR "abdominal neoplasms" OR "intra-abdominal neoplasms” OR "abdominal pelvic" OR "stomach” OR "gastrointestinal" OR "gastric"), ("Radiotherapy, Conformal" OR "3D radiotherapy" OR "tridimensional radiotherapy" OR “3D RT” OR “3DCRT” OR “CRT”), (“Conventional radiotherapy" OR " $2 \mathrm{D}$ radiotherapy" OR " $2 \mathrm{D}$ RT" OR "standard radiotherapy"). The articles were selected based on critical evaluation using the instruments (scores) proposed by Jadad and Oxford; references with greater strength of evidence were used. Recommendations were prepared from discussion with the writing group, composed of 14 members of the Brazilian Society of Radiotherapy. The guideline was reviewed by an independent group specializing in evidence-based clinical guidelines. After completion, the guideline was made available for public consultation for 15 days and the suggestions for- warded to the writers for evaluation and consideration (possible incorporation)into the final text.

\section{Grade of Recommendation and Strength of EVIDENCE}

A. Experimental or observational studies of higher consistency.

B. Experimental or observational studies of lower consistency.

C. Case reports (non-controlled studies).

D. Opinions without critical evaluation, based on consensus, physiological studies, or animal models.

\section{Objective}

To assess the most appropriate method of radiation therapy for the treatment of patients with abdominal tumors.

\section{Conflict OF InTEREST}

No conflict of interest informed.

\section{INTRODUCTION}

Radiotherapy is used in at least one phase of treatment in the main abdominal malignant tumors, including the stomach, pancreas, biliary tract and soft tissue sarcomas.

In stomach cancer, radiotherapy is performed after surgery (adjuvant) in tumors staged as locally advanced $(\mathbf{A})^{1}(\mathbf{B})$, ${ }^{2,3}$ in patients with positive margins and, as a palliative treatment, in inoperable tumors and in patients with high surgical risk $(\mathbf{B}) .4,5$

In pancreatic cancer, radiotherapy is indicated after surgery (adjuvant) to prevent recurrence of locoregional disease (B) $)^{6-8}$ Another application is for unresectable tumors in order to make them surgically resectable, preferably associated with chemotherapy $(\mathbf{B}) .^{9,10}$ 
For malignant tumors of the biliary tract, radiotherapy has the function of controlling microscopic foci of residual disease after surgical resection $(\mathbf{B})^{11,12}$ or palliative treatment for inoperable tumors, including the use of high doses of radiation $(\mathbf{B}) .{ }^{13}$

Sarcomas of the abdominal area generally originate in the retroperitoneal space. Radiotherapy has a primary role in these tumors in order to decrease local recurrence rates after surgery $(\mathbf{B}){ }^{14-16}$

Radiotherapy has evolved in recent decades thanks to the advances of computer systems that allow the recognition of internal body structures. Such recognition is performed by imaging tests on the patient, generally using computed tomography. The most accurate dose distribution, reaching the region to be treated while sparing the normal organs, is obtained thanks to the information passed onto the radiotherapy device by the computerized planning system developed. This form of dose delivery is known as the conformal technique. In addition to the computer program showing the radiation dose distribution within the patient's body, it creates dose intensity charts for each organ or target volume. This allows obtaining information on the potential toxicity of these organs and whether the tumor is being treated appropriately $(\mathbf{D}) \cdot{ }^{17}$

In the abdominal area, where there are several organs sensitive to radiation, such as the liver, pancreas, small intestine, spinal cord, spleen and kidneys, the use of conformal radiotherapy becomes the minimally recommended technique for patient safety $(\mathbf{D}) \cdot{ }^{17}$

Based on clinical experience with complications related to radiotherapy, a standard dose limit per volume of the normal tissue was created, called Quantec (Quantitative Analysis of Normal Tissue Effects in the Clinic) (D).${ }^{18}$ This standardization is recommended worldwide and currently as a practice guide for conducting radiotherapy on all parts of the body. It is only possible to know the dose quantification using the conformal technique.

For the reasons above, conventional radiotherapy should be dismissed if the area to be treated includes organs that are sensitive to radiation, such as the abdominal area, given that this technique does not provide information about the distribution of the dose to these organs.

\section{IS THE IRRADIATION OF THE ABDOMINAL AREA USING CONFORMAL RADIOTHERAPY SUPERIOR WHEN COMPARED TO CONVENTIONAL RADIOTHERAPY?}

Stomach tumors

Dosimetric studies show the superiority of conformal radiotherapy over conventional radiotherapy consider- ing some criteria, such as lower irradiation to the kidneys and spinal cord with a smaller volume in these organs receiving higher doses of radiation $(\mathbf{B})^{19-25}$ and better irradiation of targets of interest such as stomach bed and lymphonodular drainage regions $(\mathbf{A})^{1}(\mathbf{B}),{ }^{20,23}$ clearly showing the superiority of conformal radiotherapy compared to conventional, in terms of safety and dose distribution.

\section{Pancreatic and biliary tract tumors}

Retrospective studies with dosimetric analysis have shown the advantages of the conformal technique (B) ${ }^{26}$ Noncomparative prospective studies show the importance of correct identification of the site to be irradiated and organs at risk $(\mathbf{B})^{27,28}(\mathbf{C})^{29}$ and the importance of determining the dose in partially irradiated organs and its association with late onset toxicity $(\mathbf{D}){ }^{30-32}$

Studies evaluating the planning of conformal radiotherapy with radiation field entry at different angles showed better clinical outcomes, making conformal radiotherapy superior to conventional radiotherapy in the planning of radiotherapy for tumors in the pancreas and biliary tract $(\mathbf{B})^{23,25,33-36}(\mathbf{D}){ }^{37,38}$

\section{Soft tissue sarcomas}

Dosimetric studies have shown better dose distribution in areas of the abdomen where sarcomas usually originate both in adults $(\mathbf{B})^{35,39}(\mathbf{D})^{40}$ and children $(\mathbf{B}),{ }^{41}$ when the conformal technique was used.

All studies used computerized planning systems that allowed the recognition of target volumes and organs at risk by creating charts with dose distribution by volume (dose/volume histograms) enabling a suitable analysis of the dose distribution in normal tissues and the choice the best technique.

In addition, the conformal technique allows the selection of the treatment plan that best fits each case, respecting individual peculiarities and increasing multidisciplinary integration.

\section{Recommendation}

Conformal radiotherapy is superior for irradiation of the abdominal area compared to conventional radiotherapy, demonstrating superiority in terms of safety and dose distribution in stomach tumors. Conformal radiotherapy with the entry of radiation fields at different angles has shown better clinical outcomes for pancreas and biliary duct tumors. In soft tissue sarcomas, the use of a computerized planning system that allows dose/volume histograms to be produced is recommended. 
IS THERE LESS TOXICITY IN THE USE OF CONFORMAL RADIOTHERAPY COMPARED TO CONVENTIONAL RADIOTHERAPY FOR ABDOMINAL TUMORS?

Stomach tumors

The complications occurring most often in the irradiation of stomach bed and/or upper abdomen are enteropathy, nephropathy, liver disease, heart disease and lung disease associated with radiation $(\mathbf{A})^{1,2}(\mathbf{B})^{19,21,24,25,33,43,45,47-50}(\mathbf{C})^{44}(\mathbf{D}){ }^{46}$

Within the scope of gastric cancer treatment, significant rates of toxicity associated with the conventional technique of irradiation were observed in a prospective cohort study, with $33 \%$ of gastrointestinal complications at grade III or higher, and $17 \%$ of patients disqualified for ending the proposed treatment, with radiotherapy and chemotherapy as adjuvants to radical surgical treatment (A). ${ }^{1,42}$

Institutional series with prospective cohort studies in which patients received conformal radiotherapy showed lower rates of treatment-related complications, compared to rates observed with conventional radiotherapy, as well as a lower incidence of treatment discontinuation $(\mathbf{B})^{43,45}(\mathbf{C}) .^{44}$ Other series with conformal radiotherapy reported varying levels of grade III or higher gastrointestinal complications, from zero to about $57 \%$, which can also be credited to more toxic chemotherapy regimens, although still lower than the historical rates with conventional radiotherapy $(\mathbf{B})^{24,33,50-52}(\mathbf{D}){ }^{46}$

\section{Pancreatic and biliary tract tumors}

Prospective studies show the relationship between dose and volume to an organ at risk, such as the kidneys, liver, stomach and small intestine, and the complication rates of these organs $(\mathbf{B}){ }^{47,53}$ The main complication reported when there is an excess dose is decrease in renal function when the kidney's dose is greater than its tolerance $(\mathbf{B}) .{ }^{54}$

Assessments of the dose received by irradiated organ volume show the tolerance thresholds below which there is no toxicity $(\mathbf{B})^{55-61}(\mathbf{D}){ }^{62}$ Several prospective studies associate dosimetric parameters and toxicity of the organs at risk, showing lower toxicity with conformal therapy compared to conventional radiotherapy $(\mathbf{B})^{20,63,64}(\mathbf{C})^{65}(\mathbf{D}) .^{66-73}$

\section{Sarcomas}

Late complications that can occur with radiotherapy in abdominal sarcomas include enteritis, perforation, fistula, and bowel obstruction (D). ${ }^{74}$ This may increase the number of hospital admissions and emergency laparotomy. Furthermore, the involvement of the kidneys by scattered radiation can cause dialytic kidney failure if the dose limits are not respected $(\mathbf{D}){ }^{71}$
The morbidity associated with conformal radiotherapy is lower than that of the conventional technique (D) ${ }^{75,76}$ There are reports of significant toxicity rates associated with the conventional technique, with need for hospital intervention or progress to bowel obstruction $(\mathbf{B}) .{ }^{16}$

Institutional series in which patients received conformal radiotherapy showed low rates of treatment-related complications, such as bleeding, intestinal obstruction and nephropathy $(\mathbf{B})^{77,78}(\mathbf{D}) .^{79,80}$

\section{Recommendation}

The use of conformal radiotherapy compared to conventional radiotherapy for gastric tumors shows less complications and discontinuation of treatment. In pancreatic and biliary duct tumors, there is less toxicity with conformal radiotherapy compared to the conventional technique. There is a lower morbidity rate associated with conformal radiotherapy in abdominal sarcomas.

\section{IS THERE A DIFFERENCE IN THE EFFECTIVENESS OF CONFORMAL AND CONVENTIONAL RADIOTHERAPY?}

Stomach tumors

In a retrospective study that assessed two consecutive historical cohort studies, there was better relapse-free survival and distant metastasis-free survival for patients with gastric cancer surgery undergoing adjuvant treatment with conformal radiotherapy compared to conventional radiotherapy. In this study, in addition to the statistically significant difference in favor of conformal radiotherapy in terms of relapse-free survival $(\mathrm{p}=0.03)$ and distant metastasis-free survival $(\mathrm{p}=0.05)$ at 5 years, the authors found, in a multivariate analysis, that the use of planning techniques with computed tomography was predictive for improved loco-regional control, relapse-free survival, distant metastasis-free survival and overall survival (hazard ratio: 0.41, $\mathrm{p}=0.005)(\mathbf{B}){ }^{45}$

Prospective series data that used conformal radiotherapy technique demonstrate overall survival rates ranging from 70 to $88 \%$ and recurrence-free survival ranging from 64 to $70 \%$ at two years (B), ${ }^{47,49}$ suggesting better rates than those obtained in a prospective cohort study with conventional radiotherapy, with an overall survival of $58 \%$ and relapse-free survival of $55 \%$ at two years $(\mathbf{A}) .{ }^{1,42}$

\section{Pancreatic and biliary tract tumors}

Prospective cohort studies with conformal radiotherapy show local control rates comparable or superior to those achieved with conventional radiotherapy $(\mathbf{B})^{81-83}(\mathbf{D}){ }^{84}$ There is no clear difference in the effectiveness of mea- 
surable tumor control between conformal and conventional techniques at the present time, according to prospective and randomized studies.

\section{Sarcomas}

Retrospective study data demonstrate disease-free survival rates at five years of $28-60 \%$ in patients treated with conventional radiotherapy $(\mathbf{B})^{85}(\mathbf{D}) .^{79}$ Similarly, the series of patients treated with conformal radiotherapy have shown local control rates varying from 20 to $69 \%(\mathbf{B})^{78,86}(\mathbf{D}),{ }^{79}$ with no difference between the effectiveness of conformal or conventional radiotherapy treatments.

Conformal radiotherapy is considered the minimum standard technique for the abdominal area and serves as a basis for comparison in studies that assess more modern techniques such as intensity modulated radiation therapy (IMRT) and image-guided radiation therapy $($ IGRT $)(\mathbf{B})^{19}(\mathbf{B}) .{ }^{87-90}$

\section{Recommendation}

There is no evidence of higher curability with conformal radiotherapy compared to conventional radiotherapy. The need to assess the dose distributed to the organs at risk and prospective data with lower toxicity are important enough to justify the recommendation of conformal radiotherapy as the minimally acceptable technique for radiotherapy in abdominal tumors.

\section{RefEREnCES}

1. Macdonald JS, Smalley SR, Benedetti J, et al. Chemoradiotherapy after surgery compared with surgery alone for adenocarcinoma of the stomach or gastroesophageal junction. N Engl J Med 2001; 345:725-30.

2. Kevin R Kozak, Jhon S. Moody The survival impact of the intergroup 0116 trial on patients with gastric cancer. Int J Radiat Oncol Biol Phys 2008; 72: 517-21.

3. Sung Kim, Do Hoon Lim, Jeeyun Lee, et al. An Observational Study suggesting clinical benefit for adjuvant postoperative chemoradiation in a population of over 500 cases after gastric resection with D2 nodal dissection for adenocarcinoma of the stomach. Int J Radiat Oncol Biol Phys 2005, 63: 1279-85.

4. Klaasen DJ, MacIntyre JM, Catton GE, et al. Treatment of locally unresectable cancer of the stomach and pancreas: a randomized comparison of 5- fluorouracil alone with radiation plus concurrent and maintenance 5- fluorouracil. An Eastern Cooperative Oncology Group Study. J clin Oncol 1985: 373

5. Tsukiyama I, Akine Y, Kajiura Y, et al. Radiation Therapy for advanced gastric cancer. Int J Radiat Oncol Biol Phys 1988; 15:123.

6. Kalser MH, Ellenberg SS. Further evidence of effective adjuvant combined radiation and chemotherapy following curative resection of pancreatic cancer. Gastrointestinal Tumor Study Group. Cancer 1987; 9: 2006-10.

7. Corsini MM, Miller RC, Haddock MG, et al. Adjuvant radiotherapy and chemotherapy for pancreatic carcinoma: the Mayo Clinic experience (19752005). J Clin Oncol 2008; 26: 3511-6.

8. Herman JM, Swartz MJ, Hsu CC, et al. Analysis of fluorouracil-based adjuvant chemotherapy and radiation after pancreaticoduodenectomy for ductal adenocarcinoma of the pancreas: results of a large, prospectively collected database at the Johns Hopkins Hospital. J Clin Oncol 2008; 26: 3503-10.

9. Evans DB, Varadhachary GR, Crane CH, et al. Preoperative gemcitabinebased chemoradiation for patients with resectable adenocarcinoma of the pancreatic head. J Clin Oncol 2008; 26:3496-502.
10. Varadhachary GR, Wolff RA, Crane CH, et al. Preoperative gemcitabine and cisplatin followed by gemcitabine-based chemoradiation for resectable adenocarcinoma of the pancreatic head. J Clin Oncol 2008; 26: 3487-95.

11. Kraybill WG, Lee H, Picus J, et al. Multidisciplinary treatment of biliary tract cancers. J Surg Oncol 1994; 55:239.

12. Todoroki T, Ohara K, Kawamoto T, et al. Benefits of adjuvant radiotherapy after radical resection of locally advanced main hepatic duct carcinoma. Int J Radiat Oncol Biol Phys 2000; 46:581

13. Ben-Josef E, Normolle D, Ensminger WD, et al. Phase II trial of high-dose conformal radiation therapy with concurrent hepatic artery floxuridine for unresectable intrahepatic malignancies. J Clin Oncol 2005; 23:8739.

14. Stoeckle E, Coindre JM, Bonvalot S, et al. Prognostic factors in retroperitoneal sarcoma: a multivariate analysis of a series of 165 patients of the French Cancer Center Federation Sarcoma Group. Cancer 2001; 92:359.

15. Heslin MJ, Lewis JJ, Nadler E, et al. Prognostic factors associated with longterm survival for retroperitoneal sarcoma: implications for management. J Clin Oncol 1997; 15:2832

16. Catton CN, O'Sullivan B, Kotwall C, et al. Outcome and prognosis in retroperitoneal soft tissue sarcoma. Int J Radiat Oncol Biol Phys 1994; 29:1005,

17. Almeida CE, Haddad CK, Ferrigno R. A evolução técnica da radioterapia externa. In: Sociedade Brasileira de Radioterapia. Radioterapia Baseada em Evidências. Recomendações da Sociedade Brasileira de Radioterapia. $1^{\text {a }}$ Edição. São Paulo: SBRT. Capítulo 2, pág. 21-6.

18. Marks LB, Haken RKT, and Martel MK. Quantitative analyses of normal tissue effects in the clinic. Int J Radiat Oncol Biol Phys 2010; 76 (3) Supp: 1 - 160.

19. Milano MT, Garofalo MC, Chmura SJ, Farrey K, Rash C, Heimann R, Jani $\mathrm{AB}$. Intensity-modulated radiation therapy in the treatment of gastric cancer: early clinical outcome and dosimetric comparison with conventional techniques. Br J Radiol. 2006;79(942):497-503.

20. Pemberton L, Coote J, Perry L, Khoo VS, Saunders MP. Adjuvant chemoradiotherapy for gastric carcinoma: dosimetric implications of conventional gastric bed irradiation and toxicity. Clin Oncol (R Coll Radiol) 2006;18(9):663-8.

21. Wieland P, Dobler B, Mai S, Hermann B, Tiefenbacher U, Steil V, Wenz F, Lohr F. IMRT for postoperative treatment of gastric cancer: covering large target volumes in the upper abdomen: a comparison of a step-and-shoot and an arc therapy approach. Int J Radiat Oncol Biol Phys. 2004;15;59(4):123644.

22. El-Hossiny HA, Diab NA, El-Taher MM. A Comparative Dosimetric Study of Adjuvant 3D Conformal Radiotherapy for Operable Stomach Cancer Versus AP-PA Conventional Radiotherapy in NCI-Cairo. J Egypt Natl Canc Inst. 2009;21(3):197-202.

23. Leong T, Willis D, Joon DL, Condron S, Hui A, Ngan SY. 3D conformal radiotherapy for gastric cancer--results of a comparative planning study Radiother Oncol. 2005;74(3):301-6.

24. Wals A, Contreras J, Macías J, Fortes I, Rivas D, González P, Herruzo I. Damage assessment in gastric cancer treatment with adjuvant radiochemotherapy: calculation of the NTCP's from the differential HDV of the organs at risk. Clin Transl Oncol. 2006;8(4):271-8.

25. Marcenaro M, Foppiano F, Durzu S, Barra S, Corvò R. Kidney-sparing radiotherapy by multiple-field three-dimensional technique in the postoperative management of patients with gastric cancer: comparison with standard two-field conformal technique. Tumori. 2006;92(1):34-40.

26. Chu JC, Solin LJ, Hwang CC, Kesller H, Hanks GE. Three-dimensional dosimetric comparison of radiation therapy treatment planning oh the pancreas. Med Dosim. 1992; 17(4):199-203.

27. Tsujita N, Yamaguchi S, Murakami R, Hattori T, Maruyama M, Nakaguchi $\mathrm{Y}$, et al. Impact of setup error and anatomical change on dose distribution during conventional radiation therapy. Nihon Hoshasen Gijutsu Gakkai Zasshi. 2011;67(12):1559-64.

28. Ahmad N, Attia G, El-Ghoneimy E, Radwan A, El-Badawy S. Conventional (2D) Versus Conformal (3D) Techniques in Radiotherapy for Malignant Pediatric Tumors: Dosimetric Perspectives. J Egypt Natl Canc Inst. 2009; 21(4):309-14.

29. Juan-Senabre XJ, Ferrer-Albiach C, Rodríguez-Cordón M, Santos-Serra A, López-Tarjuelo J, Calzada-Feliu S. Retroperitoneal tumour radiotherapy: clinical improvements using kilovoltage cone beam computed tomography. Clin Transl Oncol. 2009;11(4):253-6

30. Yorke ED, Kutcher GJ, Jackson A, Ling CC. Probability of radiation-induced complications in normal tissues with parallel architecture under conditions of uniform whole or partial organ irradiation. Radiother Oncol. 1993; 26(3):226-37. 
31. Lawrence TS, Ten Haken RK, Kessler ML, Robertson JM, Lyman JT, Lavigne $\mathrm{ML}$, et al. The use of 3-D dose volume analysis to predict radiation hepatitis. Int J Radiat Oncol Biol Phys. 1992;23(4):781-8.

32. Howell RM, Scarboro SB, Taddei PJ, Krishnan S, Kry SF, Newhauser WD Methodology for determining doses to in-field, out-of-field and partially in-field organs for late effects studies in photon radiotherapy. Phys Med Biol. 2010;55(23):7009-23

33. Soyfer V, Corn BW, Melamud A, Alani S, Tempelhof H, Agai R, et al. Threedimensional non-coplanar conformal radiotherapy yields better results than traditional beam arrangements for adjuvant treatment of gastric cancer. Int J Radiat Oncol Biol Phys. 2007;69(2):364-9.

34. Brown MW, Ning H, Arora B, Albert PS, Poggi M, Camphausen K, Citrin D. A dosimetric analysis of dose escalation using two intensity-modulated radiation therapy techniques in locally advanced pancreatic carcinoma. Int J Radiat Oncol Biol Phys. 2006;65(1):274-83.

35. Nevinny-Stickel M, Seppi T, Poljanc K, Forthuber BC, Posch A, Lechner J, et al. Competing irradiation techniques for para-aortic lymph nodes: dose distribution and NTCP for the kidney. Int J Radiat Oncol Biol Phys. 2005;63(4):1206-13

36. Vieillot S, Azria D, Riou O, Moscardo CL, Dubois JB, Aillères N, Fenoglietto P. Bilateral kidney preservation by volumetric-modulated arc therapy (RapidArc) compared to conventional radiation therapy (3D-CRT) in pancreatic and bile duct malignancies. Radiat Oncol. 2011;6:147.

37. Murphy JD, Chang DT, Abelson J, Daly ME, Yeung HN, Nelson LM, Koong AC. Cost-effectiveness of modern radiotherapy techniques in locally advanced pancreatic cancer. Cancer. 2012;118(4):1119-29.

38. Higgins PD, Sohn JW, Fine RM, Schell MC.Three-dimensional conformal pancreas treatment: comparison of four- to six-field techniques.Int J Radiat Oncol Biol Phys. 1995;31(3):605-9.

39. Yovino S, Poppe M, Jabbour S, David V, Garofalo M, Pandya N, et al. Intensitymodulated radiation therapy significantly improves acute gastrointestinal toxicity in pancreatic and ampullary cancers. Int J Radiat Oncol Biol Phys 2010; 79(1): 158-62.

40. Gearheart DM, Walker P, Colleti BS, Modur RS. An improved approach to external beam radiation therapy for intra-abdominal cavity lesions for rural câncer centers. Med Dosim 2007; 32(4): 271-7.

41. Paulino AC, Ferenci MS, Chiang KY, Nowlan AW, Marcus RB Jr. Comparison of conventional to intensity modulated radiation therapy for abdominal neuroblastoma. Pediatr Blood Cancer 2006; 46(7):739-44

42. Smalley SR, Benedetti JK, Haller DG, Hundahl SA, Estes NC, Ajani JA, et al. Updated analysis of SWOG-directed intergroup study 0116: a phase III trial of adjuvant radiochemotherapy versus observation after curative gastric cancer resection. J Clin Oncol. 2012;30(19):2327-33.

43. Minn AY, Hsu A, La T, Kunz P, Fisher GA, Ford JM, et al. Comparison of intensity-modulated radiotherapy and 3-dimensional conformal radiotherapy as adjuvant therapy for gastric cancer. Cancer. 2010;116(16):3943-52

44. Ringash J, Khaksart SJ, Oza A, Couture J, Japp B, Moore M, et al. Postoperative radiochemotherapy for gastric cancer: adoption and adaptation. Clin Oncol (R Coll Radiol). 2005;17(2):91-5.

45. Chang AT, Ng WT, Law AL, Ku KM, Lee MC, Lee AW. Adjuvant chemoradiation for resected gastric cancer: a 10-year experience. Gastric Cancer. 2011;14(1):63-71.

46. Kassam Z, Lockwood G, O’brien C, Brierley J, Swallow C, Oza A,et al. Conformal radiotherapy in the adjuvant treatment of gastric cancer: Review of 82 cases. Int J Radiat Oncol Biol Phys. 2006;65(3):713-9.

47. Jansen EP, Saunders MP, Boot H, Oppedijk V, Dubbelman R, Porritt B, et al. Prospective study on late renal toxicity following postoperative chemoradiotherapy in gastric cancer. Int J Radiat Oncol Biol Phys. 2007;67(3):781-5.

48. Welz S, Hehr T, Kollmannsberger C, Bokemeyer C, Belka C, Budach W. Renal toxicity of adjuvant chemoradiotherapy with cisplatin in gastric cancer. Int J Radiat Oncol Biol Phys. 2007;69(5):1429-35.

49. Alani S, Soyfer V, Strauss N, Schifter D, Corn BW. Limited advantages of intensitymodulated radiotherapy over 3D conformal radiation therapy in the adjuvant management of gastric cancer. Int J Radiat Oncol Biol Phys. 2009;74(2):562-6.

50. Boda-Heggemann J, Hofheinz RD, Weiss C, Mennemeyer P, Mai SK, Hermes $\mathrm{P}$, et al. Combined adjuvant radiochemotherapy with IMRT/XELOX improves outcome with low renal toxicity in gastric cancer. Int J Radiat Oncol Biol Phys. 2009;75(4):1187-95.

51. Leong T, Joon DL, Willis D, Jayamoham J, Spry N, Harvey J, et al. Adjuvant chemoradiation for gastric cancer using epirubicin, cisplatin, and 5-fluorouracil before and after three-dimensional conformal radiotherapy with concurrent infusional 5-fluorouracil: a multicenter study of the Trans-Tasman Radiation Oncology Group. Int J Radiat Oncol Biol Phys. 2011;79(3):690-5.
52. Arcangeli G, Saracino B, Arcangeli G, Angelini F, Marchetti P, Tirindelli Danesi D.Postoperative adjuvant chemoradiation in completely resected locally advanced gastric cancer. Int J Radiat Oncol Biol Phys. 2002;54(4):1069-75.

53. Dewit L, Anninga JK, Hoefnagel CA, Nooijen WJ. Radiation injury in the human kidney: a prospective analysis using specific scintigraphic and biochemical endpoints. Int J Radiat Oncol Biol Phys. 1990; 19(4):977-83.

54. May KS, Khushalani NI, Chandrasekhar R, Wilding GE, Iyer RV, Ma WW, et al. Analysis of clinical and dosimetric factors associated with change in renal function in patients with gastrointestinal malignancies after chemoradiation to the abdomen.Int J Radiat Oncol Biol Phys. 2010;76(4):1193-8.

55. Xu ZY, Liang SX, Zhu J, Zhu XD, Zhao JD, Lu HJ, et al. Prediction of radiationinduced liver disease by Lyman normal-tissue complication probability model in three-dimensional conformal radiation therapy for primary liver carcinoma. Int J Radiat Oncol Biol Phys. 2006;65(1):189-95.

56. Cheng JC, Wu JK, Huang CM, Liu HS, Huang DY, Cheng SH, et al. Radiationinduced liver disease after three-dimensional conformal radiotherapy for patients with hepatocellular carcinoma: dosimetric analysis and implication. Int J Radiat Oncol Biol Phys. 2002;54(1):156-62.

57. Cheng JC, Wu JK, Huang CM, Huang DY, Cheng SH, Lin YM, et al. Radiationinduced liver disease after radiotherapy for hepatocellular carcinoma: clinical manifestation and dosimetric description. Radiother Oncol. 2002;63(1):41-5.

58. Nakamura A, Shibuya K, Matsuo Y, Nakamura M, Shiinoki T, Mizowaki T, Hiraoka M. Analysis of dosimetric parameters associated with acute gastrointestinal toxicity and upper gastrointestinal bleeding in locally advanced pancreatic cancer patients treated with gemcitabine-based concurrent chemoradiotherapy. Int J Radiat Oncol Biol Phys. 2012;84(2):369-75.

59. Kim H, Lim do H, Paik SW, Yoo BC, Koh KG, Lee JH, et al. Predictive factors of gastroduodenal toxicity in cirrhotic patients after three-dimensional conformal radiotherapy for hepatocellular carcinoma. Radiother Oncol 2009;93(2):302-6

60. Lee IJ, Seong J, Shim SJ, Han KH. Radiotherapeutic parameters predictive of liver complications induced by liver tumor radiotherapy. Int J Radiat Oncol Biol Phys. 2009;73(1):154-8

61. Kim TH, Kim DY, Park JW, Kim SH, Choi JI, Kim HB, et al. Dose-volumetric parameters predicting radiation-induced hepatic toxicity in unresectable hepatocellular carcinoma patients treated with three-dimensional conformal radiotherapy. Int J Radiat Oncol Biol Phys. 2007;67(1):225-31.

62. Ng A, Brock KK, Sharpe MB, Moseley JL, Craig T, Hodgson DC. Individualized $3 \mathrm{D}$ reconstruction of normal tissue dose for patients with long-term followup: a step toward understanding dose risk for late toxicity. Int J Radiat Oncol Biol Phys. 2012;84(4):e557-63.

63. Köst S, Dörr W, Keinert K, Glaser FH, Endert G, Herrmann T. Effect of dose and dose-distribution in damage to the kidney following abdominal radiotherapy. Int J Radiat Biol. 2002;78(8):695-702.

64. Dawson LA, Normolle D, Balter JM, McGinn CJ, Lawrence TS, Ten Haken RK. Analysis of radiation-induced liver disease using the Lyman NTCP model. Int J Radiat Oncol Biol Phys. 2002;53(4):810-21.

65. Nichols RC Jr, Huh SN, Prado KL, Yi BY, Sharma NK, Ho MW, et al. Protons offer reduced normal-tissue exposure for patients receiving postoperative radiotherapy for resected pancreatic head cancer. Int J Radiat Oncol Biol Phys. 2012;83(1):158-63.

66. Stewart FA. Radiation nephropathy after abdominal irradiation or total body irradiation. Radiat Res. 1995;143(3):235-7.

67. Rodríguez ML, Martín MM, Padellano LC, Palomo AM, Puebla YI Gastrointestinal toxicity associated to radiation therapy. Clin Transl Oncol. 2010;12(8):554-61

68. De Bari B, Pointreau Y, Rio E, Mirabel X, Mornex F. Normal tissue tolerance to external beam radiation therapy: liver. Cancer Radiother. 2010;14(4-5):344-9.

69. Wong Hee Kam S, Huguet F. Normal tissue tolerance to external beam radiation therapy: kidney. Cancer Radiother. 2010;14(4-5):340-3.

70. Pan CC, Kavanagh BD, Dawson LA, Li XA, Das SK, Miften M, Ten Haken RK. Radiation-associated liver injury. Int J Radiat Oncol Biol Phys. 2010;76(3 Suppl):S94-100.

71. Dawson LA, Kavanagh BD, Paulino AC, Das SK, Miften M, Li XA, et al. Radiationassociated kidney injury. Int J Radiat Oncol Biol Phys. 2010;76(3 Suppl):S108-15.

72. Kavanagh BD, Pan CC, Dawson LA, Das SK, Li XA, Ten Haken RK, Miften M. Radiation dose-volume effects in the stomach and small bowel. Int J Radiat Oncol Biol Phys. 2010;76(3 Suppl):S101-7.

73. Liang SX, Zhu XD, Xu ZY, Zhu J, Zhao JD, Lu HJ, et al. Radiation-induced liver disease in three-dimensional conformal radiation therapy for primary liver carcinoma: the risk factors and hepatic radiation tolerance. Int J Radiat Oncol Biol Phys. 2006;65(2):426-34 
74. Kepka L, DeLaney TF, Suit HD, Goldberg SI. Results of radiation therapy for unresected soft-tissue sarcomas. Int J Radiat Oncol Biol Phys. 2005;63(3):852-9.

75. Purdy JA. Dose to normal tissues outside the radiation therapy patient's treated volume: a review of different radiation therapy techniques. Health Phys. 2008;95(5):666-76.

76. DeLaney TF, Trofimov AV, Engelsman M, Suit HD. Advanced-technology radiation therapy in the management of bone and soft tissue sarcomas. Cancer Control. 2005;12(1):27-35.

77. Kinsella TJ, Sindelar WF, Lack E, Glatstein E, Rosenberg SA. Preliminary results of a randomized study of adjuvant radiation therapy in resectable adult retroperitoneal soft tissue sarcomas. J Clin Oncol. 1988;6(1):18-25.

78. Jones JJ, Catton CN, O'Sullivan B, Couture J, Heisler RL, Kandel RA, Swallow CJ. Initial results of a trial of preoperative external-beam radiation therapy and postoperative brachytherapy for retroperitoneal sarcoma. Ann Surg Oncol. 2002;9(4):346-54.

79. Pawlik TM, Pisters PW, Mikula L, Feig BW, Hunt KK, Cormier JN, et al. Long-term results of two prospective trials of preoperative external beam radiotherapy for localized intermediate- or high-grade retroperitoneal soft tissue sarcoma. Ann Surg Oncol. 2006;13(4):508-17.

80. Zlotecki RA, Katz TS, Morris CG, Lind DS, Hochwald SN. Adjuvant radiation therapy for resectable retroperitoneal soft tissue sarcoma: the University of Florida experience. Am J Clin Oncol. 2005;28(3):310-6.

81. Milano MT, Chmura SJ, Garofalo MC, Rash C, Roeske JC, Connell PP, et al. Intensity-modulated radiotherapy in treatment of pancreatic and bile duct malignancies: toxicity and clinical outcome. Int J Radiat Oncol Biol Phys. 2004;59(2):445-53.

82. Masson-Côté L, Couture C, Fortin A, Dagnault A. Postoperative radiotherapy for lung cancer: improvement in locoregional control using three-dimensional compared with two-dimensional technique. Int J Radiat Oncol Biol Phys. 2011;80(3):686-91.
83. Mornex F, Girard N, Beziat C, Kubas A, Khodri M, Trepo C, Merle P. Feasibility and efficacy of high-dose three-dimensional-conformal radiotherapy in cirrhotic patients with small-size hepatocellular carcinoma non-eligible for curative therapies - mature results of the French Phase II RTF-1 trial. Int J Radiat Oncol Biol Phys. 2006;66(4):1152-8

84. Cohen EP, Robbins ME. Radiation nephropathy. Semin Nephrol. 2003; 23(5):486-99.

85. Lindberg RD, Martin RG, Romsdahl MM, Barkley HT Jr. Conservative surgery and postoperative radiotherapy in 300 adults with soft-tissue sarcomas. Cancer. 1981;47(10):2391-7.

86. Greiner RH, Munkel G, Blattmann H, Coray A, Kann R, Pedroni E, Thum P. Conformal radiotherapy for unresectable retroperitoneal soft tissue sarcoma. Int J Radiat Oncol Biol Phys. 1992;22(2):333-41.

87. ChengJC, Wu JK, Huang CM, Liu HS, Huang DY, Tsai SY, et al. Dosimetric analysis and comparison of three-dimensional conformal radiotherapy and intensitymodulated radiation therapy for patients with hepatocellular carcinoma and radiation-induced liver disease. Int J Radiat Oncol Biol Phys. 2003;56(1):229-34.

88. Landry JC, Yang GY, Ting JY, Staley CA, Torres W, Esiashvili N, Davis LW. Treatment of pancreatic cancer tumors with intensity-modulated radiation therapy (IMRT) using the volume at risk approach (VARA): employing dose-volume histogram (DVH) and normal tissue complication probability (NTCP) to evaluate small bowel toxicity. Med Dosim. 2002;27(2):121-9.

89. Poppe MM, Narra V, Yue NJ, Zhou J, Nelson C, Jabbour SK. A comparison of helical intensity-modulated radiotherapy, intensity-modulated radiotherapy, and 3D-conformal radiation therapy for pancreatic cancer. Med Dosim. 2011;36(4):351-7.

90. Dahele M, Skinner M, Schultz B, Cardoso M, Bell C, Ung YC. Adjuvant radiotherapy for gastric cancer: A dosimetric comparison of 3-dimensional conformal radiotherapy, tomotherapy and conventional intensity modulated radiotherapy treatment plans. Med Dosim. 2010;35(2):115-21.

\section{ERRATUM}

http://dx.doi.org/10.1590/1806-9282.61.03.290

In the article "Treatment of abdominal tumors using radiotherapy", published in the journal Rev Assoc Med Bras, vol. 61, n. 02: p.108-113, on page 108, where it reads:

"Authorship: Brazilian Society for Radiation"

It should read:

"Authorship: Brazilian Society for Radiation Oncology" 